\title{
Does Smart \& Powerful CEO Contribute to the Performance of Technology Companies?
}

\section{Elena Karnoukhova}

Master of Economic Sciences, Researcher

$\underline{\text { ORCID }}$

E-mail: elena.karnouhova@gmail.com

Corporate Finance Center, National Research University Higher School of Economics, Moscow, Russia

\section{Anastasia Stepanova}

$\mathrm{PhD}$, Associate Professor

Research Fellow

$\underline{\text { ORCID }}$

E-mail: anastasianstepanova@gmail.com

School of Finance, National Research University Higher School of Economics, Moscow, Russia

Corporate Finance Center, National Research University Higher School of Economics, Moscow, Russia

Journal of Corporate Finance Research, Vol. 13, No. 4, pp. 39-58 (2019)

DOI: https://doi.org/10.17323/j.jcfr.2073-0438.13.4.2019.39-58

Received 20 October 2019 | Peer-reviewed 10 November 2019 | Accepted 3 December 2019 


\section{Does Smart \& Powerful CEO Contribute to the Performance of Technology Companies?}

\section{Abstract}

In recent decades, innovative companies became one of the major drivers of economy worldwide. According to surveys, nearly $70 \%$ of the world's most innovative companies in 2019 are U.S. firms. However, academic studies mostly focused on the influence of the top management team and the board of director's on the firm performance, on the relationship between innovations and CEO`s preferences. However, we suppose CEO can exert a significant influence on performance of innovative companies. We strive to show which CEO characteristics could lead to higher firm value. Does highly educated CEO contribute more to innovations in hi-tech sphere? Does CEO power matter? Are founders better CEOs than newcomers or professionals for technological companies with their longer horizons and higher risks? This research uses Generalized Least Square model on a sample of 12565 firm-year observations during 2004-2015 period. For this research we used data for three innovative industries: Pharmaceuticals, Biotechnology \& Life Sciences, Software \& Services and Technology Hardware \& Equipment industries. We have hand-collected data from the CVs in CIQ database. Overall, the empirical results reveal that educational background, tenure, duality play crucial roles in explaining firm value. This study contributes to the existing literature in two aspects. First, our findings indicate that CEO characteristics play crucial roles in explaining technology firm value and performance. We demonstrated that founding CEO contributes to technology firm performance as well as the CEO with better education. Second, CEOs should be smart and powerful in order to sustain firm performance. We found that CEOs characteristics could mitigate the conflicts between different types of investors and their influence on firm performance. More specifically, CEOfounder was found to add greatly to the firm performance of Software and Pharmaceutical companies. Furthermore, the influence of CEO seems to mitigate the conflict of interest with independent active institutional investors in Hardware industry. We provided examples to prove the validity of our tests.

Keywords: CEOs characteristics, innovative companies, ownership structure, firm performance JEL classification: G32, G41 


\section{Introduction}

The subsequent logical question is why do we choose to explore an innovative firm? Primary, recent outlooks show that the companies from the sector of innovation technologies became the leaders of the global economy (Apple, Microsoft, Facebook, Amazon), surpassing oil and gas (ExxonMobil, BP) and bank industry (HSBC, JP Morgan Chase). On the other hand, the start-up activity in the technological sector is increasing over time, observing the rise in the Rate of Startup Growth of Kauffman index by $11.5 \%$ from 2013 . And, according to the UNESCO Institute of Statistics the global R\&D spending has reached a peak of almost US\$ 1.7 trillion, where the proportion of the USA is $37.9 \%$ in 2013, surpassing all other regions. Today, the major part of total spending $(70.6 \%)$ is in the business sector.

These new market developments create uncertain impacts on the innovative market. New technological firms stand under competition pressure. Thus, firms need to adjust their strategies to the new market demand. This could be delegated not only to the board of directors, but to the CEO. So, it is important to understand which characteristics of the CEO could lead to the value creation in innovative industries.

A large body of literature has researched how top management team and the board of director's influence innovations. Fu (2019) [1] linked corporate innovations and board independence in Chinese companies. The author stands for the positive impact of the short tenure of CEO on firm performance in the context of high competition. High product competition was found to have a large impact on CEO power (Sheikh, 2018 [2]). Behavioral studies in this area are focused on the CEO's motivation to promote innovations. Cho, Kim (2017) [3] show the influence of short career horizon on breakthrough innovations. Even CEO's hobby of flying airplanes was found to be positively related to the innovation output (Sunder et al. 2017 [4]).

Studies has been mostly focused on the relationship between innovations and CEO's preferences: e.g. political preferences of CEO (Han, 2019 [5]), CEO research talent (Jung, Subramanian, 2017 [6]), CEO charisma (Zhang, Ou, Wang, 2017 [7]), CEO's creative leadership (Makri, Scandura, 2010 [8]). Thus, little attention has been paid to the investigation of the CEO characteristics themselves. In this article we follow Chen, Lin, Song, Li (2011) [9] study showing how educational and professional background of CEO influences firm's innovation efforts. However, in our study we take a particular look at innovative industries. We strive to show which CEO characteristics could lead to higher firm value. Does highly educated CEO contribute more to innovations in hi-tech sphere? Does CEO power matter? Are founders better CEOs than newcomers or professionals for technological companies with their longer horizons and higher risks? This study seeks to fill these gaps.

The reasons for the fast growth of technological companies are still debatable. Scholars are trying to link their performance to the composition of board of directors, to independent directors, to ownership and capital structures. In this article we try to find out whether the leader's characteristics matter for the value creation in innovative industries. If yes, then which characteristics are more important than others. Recently, Forbes has created a new list of "the most creative and successful business minds of today". They measure four essential leadership qualities of top founders and CEOs, including media reputation for innovation, social connections, track record for value creation and investor expectations for value creation ${ }^{1}$, in an attempt to explain who stimulates innovations

These research gave us an impulse to explore different characteristics of CEO in technological companies and their influence on the firm performance of three innovative industries of US market. However, in the academic literature the simultaneous influence of type of owner and CEO characteristics on the firm performance has been neglected. In our previous paper Karnoukhova, Stepanova, Kokoreva (2019) [10] we found that different types of investors differently affect firm performance in innovative industries. So, in this study we make a next step into the understanding of how and by whom the innovations are stimulated. We still believe that different types of investors with their goals and risk preferences matter. However, now we also want to know whether highly educated, committed and powerful CEO influence the performance of companies in innovative industries.

The remainder of this study is organized as follows. Section 1 provides the introduction. Section 2 describes the literature review. The sample selection and empirical model are described in Section 3. Section 4 presents the empirical results. Finally, the conclusions are presented in Section 5.

\section{Literature review}

A large body of studies emerge with the appearance of a new group of economy`s drivers - innovative companies. However, little attention has been paid to the investigation of the innovative industry. Most of the articles focus on the relationship between $\mathrm{R} \& \mathrm{D}$ activities and the performance or innovativeness of a firm (Baysinger, Kosnik, Turk, 1991 [11]; Hoskisson et al., 2002 [12]; Cleyn, Braet, 2012 [13]; Rafiq, Salim, Russell, 2016 [14]). The deepin observation on the ownership type was presented by Hoskisson et al. (2002) [12], suggesting, that insiders tend to internal innovation as public pension funds and outsiders with professional investment funds' managers prefers

${ }^{1}$ Forbes, 2019. WHO ARE THE MOST CREATIVE AND SUCCESSFUL BUSINESS MINDS OF TODAY?

https://www.forbes.com/lists/innovative-leaders/\#11658f8426aa 
to acquire the external innovation. The same results on the relationship between foreign ownership were obtained by Chen, Lin, Lin, Hsiao (2016) [15] and Talaja (2013) [16]. However, for the sample of 138 Taiwanese firms Chen et al., (2016) [15] detect the negative relationship between the ownership concentration and the innovative performance in terms of the number of granted patents. Besides, the authors show that the presence of independent director on board positively influences on innovation strategy of a company. For the sample of 49 SMEs in the Flemish manufacturing industries Cleyn, Braet (2012) [13] show that the size of the board of directors positively impact on the placement of a new innovative product during the last two years. In this paper the authors detect higher debt recourse for the sample of innovative companies, assuming that financial institutions have more faith in the development of these type of firms. By comparing the financial performance of major US and Chinese mining firms Rafiq, Salim, Russell (2016) [14] argue that firm age plays an important role in moderating R\&D activities. They found that the maturity firm in both countries is more profitable in terms of sales (7.2\%) and profit (4.4\%) that its younger non-innovative counterpart.

On the other hand, there is an ongoing debate on the extent to which different characteristics of an innovative firm influence on its performance. Among the major feature researchers mainly distinguish the composition of the board of directors, especially the intellectual capital of innovative firms (Hull, Rothenberg, 2008 [17]; Jiménez-Jiménez, Sanz-Valle, 2011 [18]; Erisson, Qin, Wang, 2015 [19]; Héroux, Fortin, 2016 [20]), ownership structure (Gavious, Hirsh, Kaufman, 2015 [21]; Hsu, Lai, Li, 2016 [22]; Colombo, Croce, Murtinu, 2014 [23]), and industry specifications (Ching, Lieu, Hung, 2016 [24]).

Knowledge is an important source of value creating in innovative companies, that is why both the quality of personnel and corporate practices seem to impact on firm performance. Hull, Rothenberg (2008) [17] note that in low-innovation firms the stronger is the social performance of the company the better is its financial performance. The authors suggest that the moderating of social practices is a time-consuming process, which decreases therefore the management activity towards new product development. Meanwhile, Jiménez-Jiménez, Sanz-Valle (2011) [18] show that the functional diversity and the educational level of the top-management team (TMT) is positively related to innovation, whereas tenure is negatively associated with innovation. The same results were obtained by Héroux, Fortin (2016) [20]. For the sample of $163 \mathrm{~S} \& \mathrm{P} / \mathrm{TSX}$ composite index the authors found that the industry background and the competence of managers positively impact on product and process innovation, accordingly. However, the opposite result was demonstrated for the firm size and the diversity of the tenure of the board, which have both positive impact on each type of innovation. A similar attempt has been made by Erisson, Qin, Wang (2015) [19] in using the turnover of technical employee as a measure of HRM practices in innovative companies. For 582 Chinese companies in 5 high-tech industries (energy, electronic information, biotechnology, equipment manufacturing and environmental protection) the authors demonstrate the U-shape relation between the turnover of R\&D employees and the innovative performance (in terms of product and process innovation).

Recent articles devoted to the ownership structure of innovative companies distinct almost the equivalent industry classification. Examining 29 high-tech firms belonging to pyramidal groups Gavious, Hirsh, Kaufman (2015) [21] found that biotechnology firms and other high-technology firms have different ownership patterns. So, there is evidence to suggest that this could be a reason of different relationship with similar parameters. The distinction between different effect of owner-manager and individual non-manager owner on the performance of 255 Italian unlisted high-tech entrepreneurial firms was proposed by Colombo, Croce, Murtinu (2014) [23]. The main conclusion is that the higher the number of owner-manager the better is the performance through the reducing of horizontal agency costs. In contrast, for the sample of 1391 public Taiwanese firms from innovative industry Hsu, Lai, Li (2016) [22] connect the increase in foreign institutional, corporate and government ownership in line with high R\&D intensity with an upgrade in corporate transparency. Overall, the above contrary results of similar studies suggest the difference between developed and emerging countries. In addition, Ching, Lieu, Hung (2016) [24] for Taiwanese 386 firms across 25 high-tech and service sectors show the dominance of firm specific factors among performance measures.

The geographical particularity was one of the focus of later studies (Knyazeva et al., 2013 [25]; Balsmeiera, Buchwaldc, Stiebale, 2014 [26]; Boasson et al., 2015 [27]). The special study was presented by Balsmeiera, Buchwaldc, Stiebale (2014) [26], which demonstrates that the proximity of outside director significantly and positively influences on the patenting activities of German firms. For pharmaceutical and biotechnological industries, the study conducted on both emerging and developed markets show that insider ownership and scientific connections play an important role on the transaction economies by fostering the R\&D intensity, whereas the board independence is negatively related to the R\&D intensity on European market (Tereshchenko, Stepanova, 2016 [28]). Finally, further study of biotechnological industry in Korea provides the following conclusion: R\&D development are encouraged mostly by foreign linkages and governmental support (Kang, Park, 2012 [29]).

We observe that among all this studies little attention has been paid on the investigation of CEO characteristics (educational level, tenure and gender) of high-tech companies, that could encourage firm performance. Using our results, we will fill this gap in the field of corporate finance. For the future methodology we suggest to control our main hypothesis by R\&D intensity of a firm. 


\section{Methodology and data}

We verify the importance of CEOs characteristics in innovative firms. Nowadays, researchers commonly use the Eurostat and OECD classification of an innovative firms: manufacturing firms (technology intensity of sector) and service provider (knowledge intensity of sector). According to NACE Rev. 1.1 (2002) Knowledge Intensive Firms (KIF) are characterized by its high knowledge, capital intensity and the narrow degree of specialization (real estate activities, financial intermediation, post and telecommunication etc.) and manufacturing firms are divided into high (more than $4 \%$ of R\&D turnover), medium-high (between $1 \%$ and $4 \%$ of R\&D turnover), medium-low (between $1 \%$ and $4 \%$ of R\&D turnover) and low technology (less than 1\% of R\&D turnover). In this article we will consider high technology manufacturing firms: manufacturers of pharmaceuticals, medical chemicals and botanic production (22.4), manufacturers of office machinery and computers (30), manufacturers of radio, television and communication equipment and apparatus (32). In our sample we use the data from Bloomberg database, we adopt its classification, which consolidates technological industry, mentioned above. So, we will distinguish three main high-technology industry: Pharmaceuticals, Biotechnology \& Life Sciences, Software\& Services, and Hardware \&Technology Equipment.

\section{Data and descriptive statistics}

We obtained the data from Bloomberg and Capital IQ databases. We collected from Bloomberg board characteristics and financial data, including Tobin's, ROE, ROA. From Capital IQ we downloaded the data for all types of investors following their classification by institutional and strategic, including their strategies (active, passive). Moreover, CIQ provides an opportunity to collect the data for the first five major shareholders with the percentage of owned share, name, type and strategy. Firstly, we collected all firms from Russell 3000 index, the most suitable capitalization weighted equity index, which captures approximately $98 \%$ of U.S firms. This index is the benchmark widely used in scholar's studies (Crane et al., 2014 [30]; Appel et al., 2016 [31]). Thus, the first data sample for the period from 2004 to 2015 consists of 26269 firm-year observations for 2957 firms. Then, using the Bloomberg industry classification we extract 24 industry sectors. We choose only 3 from them according to our needs. We extracted 642 technological firms. We classified technological firms as Pharmaceuticals, Biotechnology \& Life Sciences (270 members), Software \& Services (250 members) and Technology Hardware \& Equipment (122 members).

From descriptive statistics in Table 1 in Appendix we observe top five major shareholders of each investor's group. Top five grey investors with active strategy own $0,4 \%$ on average, grey institutions with not active/ passive strategy own $0,5 \%$, independent institutions with active strategy own $8 \%$, independent with not active/passive $2,9 \%$, independent with passive strategy own $4 \%$, strategic owners have $8,7 \%$ on average, state own $1 \%$ on average. For the whole sample $11 \%$ of board belong to women and $77 \%$ to independent directors on average. Company age varies from 3 to 145 , which means that be exploring Russell 3000 index we investigate full range of firms, from the youngest to the oldest.

We distinguish three high-tech industries in terms of CEO characteristics, especially their knowledge formation. Table 2 in Appendix demonstrates the difference among Pharmaceuticals, Biotechnology \& Life Sciences, Software \& Services and Technology Hardware \& Equipment industries. We review that CEOs in Pharmaceuticals, Biotechnology \& Life Sciences have higher educational degree overall, and, with the highest number of $\mathrm{PhD}$ degree members. Moreover, CEOs are educated mostly in Natural Science and have Medical Doctor degree. The most part of CEO in Software \& Services possesses a Bachelor of Arts degree, and are mostly educated in Computer science. Finally, in Technology Hardware \& Equipment industry CEOs are professional in Engineering with a Bachelor of Science degree.

\section{Model specification}

We stress the hypothesis that in innovative industries Intellectual Capital is connected with firm value and could have some interference within the effectiveness of institutional investors.

As the first part of additional research we conduct an analysis of the relationship between CEO characteristics and firm performance of innovative companies (Chen, 2014 [32]):

Performance $_{\mathrm{it}}=\beta_{0}+\beta_{1} \times$ Tenure $_{\mathrm{it}}+\beta_{2} \times$ Degree $_{\mathrm{it}}+$

$+\beta_{3} \times$ Founder $_{\mathrm{it}}+\beta_{4} \times$ Gender $_{\mathrm{it}}+\beta_{5} \times$ Board $_{\mathrm{it}}+$

$+\beta_{6} \times$ Controls $_{\mathrm{it}}+\varepsilon_{\mathrm{it}}$

As the second part we imply different types of investors in previous model in order to understand whether CEO characteristics alter the relationship between investor's type and firm performance:

$$
\begin{aligned}
& \text { Performance }_{\mathrm{it}}=\beta_{0}+\beta_{1} \times \text { Tenure }_{\mathrm{it}}+ \\
& +\beta_{2} \times \text { Degree }_{\mathrm{it}}+\beta_{3} \times \text { Founder }_{\mathrm{it}}+ \\
& +\beta_{4} \times \text { Gender }_{\mathrm{it}}+\beta_{5} \times \text { Grey }_{\mathrm{it}}+ \\
& +\beta_{6} \times \text { Indep }_{\mathrm{it}}+\beta_{7} \times \text { State }_{\mathrm{it}}+ \\
& +\beta_{8} \times \text { Strategic }_{\mathrm{it}}+\beta_{9} \times \text { Board }_{\mathrm{it}}+ \\
& +\beta_{10} \times \text { Controls }_{\mathrm{it}}+\varepsilon_{\mathrm{it}}
\end{aligned}
$$

Where $i$ is the number of firm; $t$ is a year and $j$ is the proportion of shareholding held by the first five major shareholders (\%); Performance $_{i t}$ is measured by Tobin $\mathrm{Q}, \mathrm{ROA}, \mathrm{ROE} ;$ Grey $_{i t}$ is the proportion of shares held by grey institutions (\%); Indep it is the proportion of shares held by independent institutions (\%); Strategic $c_{i t}$ is the proportion of shares held by strategic owners; Top is the proportion of shares held by the top five, twenty, fifty 
shareholders (\%); Majors is the proportion of shares held by first, second, third, fourth, fifth shareholders (\%); Board $_{i t}$ is the vector of board characteristics: Board Size, Independent Director (\%), Women Director (\%). Controls $_{i t}$ is the vector of control variables including firm size, leverage, R\&D, company age, Sales growth and EBITDA volatility. We will further carefully explain and provide examples to prove the adequacy of the model. Definitions of all variables are presented in Table 3 in the Appendix.

We use GLS model estimation with robust standard deviation. We used both Fixed and Random effects model, using the Hausman test to prove the right specification. In order to avoid missing variables problem, we used windsorized variables in regression analysis. Also, we provide some evidence of an absence of endogeneity problems. We check endogeneity by IV 2SLS method. Using VIF matrix we reject multicollinearity problem.

\section{Dependent Variables}

The firm performance is measured by both accounting-based and market-based criteria. We use different corporate performance measures in order to examine both the backward-looking and forward-looking perspectives (Shan, McIver, 2011 [33]). Tobin Q is a measure of firm value and could reflect corporate governance decisions as well as liquidity and intangibility (Li et al., 2015 [34]). whereas ROA reflects the operating performance. Both measures have its advantages and disadvantages. For instance, Tobin Q is subject to price fluctuations, investors attitudes (corporate takeover abnormal returns), but is good in reflecting growth opportunities of a firm, whereas ROA is not affected by the market situation, but is focused on the current performance (Cornett et al., 2007 [35]). Thus, we expect the difference in the obtained results for different performance measures. This could give us an opportunity to compare both the effectiveness of operating and market performance of a firm. We will use Return on Equity (ROE) as a robustness check for the model specification.

\section{Independent Variables}

We use collected information about CEO: degree, the sphere of education, tenure, gender and was he/she founder. We postulate that investor could appreciate boards with higher level of educational background. Darmadi (2013) [36] found that educational qualifications positively associated with Tobin Q and ROA of 160 Indonesia Stock Exchange. Also, we assume that financial education of CEO is more importantly for bigger firms, because of their business complexity. For example, Chen (2014) [32] analyzing the relationship between R\&D intensity and board human capital on a large sample of Taiwanese electrical firms, found that CEO tenure and Board educational level positively influence on firm performance as well as R\&D activity. Different methods were applied in the field of behavioral finance. Chiang et al. (2016) [37] implicate Accounting and Business background for Senior managers. We will take method of calculation CEO degree level, used by Barker and Mueller (2002) [38]. They scaled each educational degree by four-point scale: 0 -no college degree, 1-Bachelor degree, 2- Masters, 3- Ph.D. or J.D. We also coded $\mathrm{MBA}=2$, because in most studies the authors suggest that financial education is significant measure of human capital quality. Then, we calculated Degree variable as a sum of coded scale, Tenure as a difference between 2015 and CEO appointment, Founder as a Dummy variable, which equals to 1 , if CEO is simultaneously founder or co-founder of a company, and Gender as a Dummy variable, which equals to 1 if the CEO is a man, and to 0 otherwise.

For all models we will also use the same vector of firm characteristics, that could either exacerbate the effect of ownership structure or add greatly to the firm performance. The size of board of directors is an important measure. It reflects the decision-making process within the firm. As suggested by the scholars the larger the board of directors the longer and more difficult is the arrival at a decision. But, from the alternative point of view the diversification of opinions due to different ethnical, sexual, geographical, educational, cultural and experienced members of the board give an opportunity to solve more sophisticated problems. Thus, exists the breakpoint of this double influence. The diversity of points of view present the benefit for innovative company's performance, where the professional experience as well as the educational background could matter. Thus, for the board diversification measure we include the presence of a women in the board of directors (\%Women), which is probably one of the worldwide economy trends (Terjesen et al., 2016 [39]). Women on the board presents not only the variety of opinions, they are commonly known as less risk-aversive. Furthermore, independent directors represent one of the ways of mitigation of potential agency conflicts between management and shareholders. Independence of the board are commonly viewed as a good signal of corporate governance, so, is associated with better performance (McConnell et al., 2008 [40]). In our analysis the independence of owners plays an important role because of their monitoring activity, thus, the presence of independent director on the board could potentially be the complement to the firm performance. So, we predict that higher percentage of independent directors on the board and the predominant presence of independent institutions enhance the firm value.

\section{Control variables}

In our paper we use several control variables previously applied in the academic literature. Following Lin et al. (2017) [41] we identify the potential relationship of firm performance with Firm Size (natural logarithm of total assets) and Leverage (market Value of Debt to total Market capitalization). We expect the positive relationship with firm size and negative with leverage. To measure the investment opportunities, we use antecedent growth in Sales (De-la-Hoz et al., 2016 [42]). 
Figure 1. Distribution of CEO characteristics by High-Tech industry

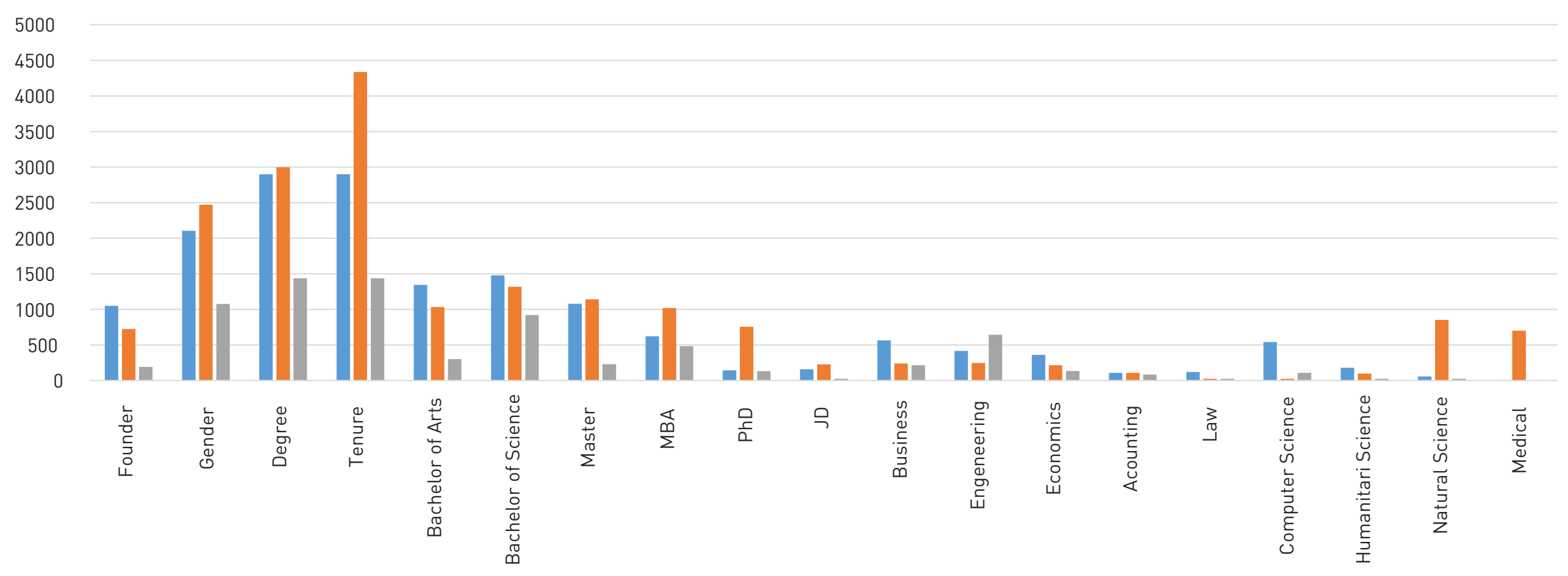

@ Soft @ Pharma nardware

Source: Capital IQ, authors calculations. On the Y-axis Number of observations. 
The specification of our research is that we emphasis the difference in ownership structure in high-tech and non-tech industries. In order to catch this difference, we include R\&D measure (logarithm of R\&D), which minimizes the effect of a drop in $\mathrm{R} \& \mathrm{D}$ ratio during IPOs equity increases (Acharya, Xu, 2016 [43]). Moreover, we develop the hypothesis that company age is connected with the presence of several types of investors in the firm, because some have preferences in stability and others in growth opportunities, some have long-term incentives and others short-term. Thus, independent institutions with long-term orientation could potentially invest more in large, stable and mature firms. Thus, we expect a positive relationship between company age, firm performance and the presence of independent institutions. We measured the company age as the difference between 2015 and the foundation year. We have collected data for firm age from CIQ database, but for missing values we hand appended the sample. It is important to mention that in the case of spin-offs, subsidiaries, parts of conglomerate, we use the date of parent company foundation, because of the information and reputation of a company. For example, GCP Applied Technologies was established as a subsidiary of W.R. Grace \& Co. in Columbia, Maryland in 2015. Its parent company spun off GCP Applied Technologies on January 28, 2016. We took the date of foundation of its parent company W.R. Grace \& $\mathrm{Co}-1854$. Talen Energy is an independent power producer founded in 2015. It was formed when the competitive power generation business of PPL Corporation was spun off and immediately combined with competitive generation businesses owned by private equity firm Riverstone Holdings. Following these transactions, PPL shareholders owned $65 \%$ of Talen's common stock and affiliates of Riverstone owned 35\%. PPL was founded in 1920. In order to link our hypothesis in terms of risk level we calculate the EBITDA volatility during three-year period as a proxy of risk level measure (Nashier et al., 2016 [44]).

\section{Empirical Results}

Following previous analysis of the ownership structure in our last paper (Karnoukhova, Stepanova, Kokoreva, 2018 [10]) we turn our view to the CEO's human capital research in innovative industry. For this purpose, we hand collected information about CEO: degree, the sphere of education, tenure, gender and was he/she founder. We have analyzed $270 \mathrm{CV}$ from Pharmaceuticals, $250 \mathrm{CV}$ from Software and $122 \mathrm{CV}$ from Hardware industry (figure 1). On the figure we see the difference in CEOs characteristics between tree innovative industries. We see that in Pharmaceutical companies, CEOs have more tenure, higher degree of education and more male CEO. In the Software industry CEOs are more likely to be founders in comparison with Hardware industry. CEOs in Software industry have on average more Bachelor degree in science than in other industries. In the Hardware industry CEOs are more likely to have a Bachelor degree in engineering than in other industries. $\mathrm{PhD}$ level of education is propagated in Pharmaceutical industry.
Firstly, we separately analyzed the influence of CEO characteristics on the firm performance (Table 1). In general, we suggested the positive influence of CEO's degree, tenure and founder $\mathrm{CEO}$ on the firm performance. However, we found that, in general, these characteristics are significant, but their signs vary across industries and specifications. The CEO-founder positively affects accounting measures of firm performance, and negatively or insignificant on market firm performance.

As we expected, we observe different influence of CEO personality on firm performance across sectors. Let us start the analysis from the Software \& Services sector. Interestingly, in this sector the only important factor for firm performance is whether the CEO is still a founder of a company. Founding CEO contributes to ROA by $0.2 \mathrm{pp}$. Difference occurs, when we compare Biotechnology and Hardware industries. And, we finally obtain convergence in firm performance measures. All in all, the higher the degree of education of CEO, the higher the firm performance. It could be argued, that, in practice, pharmaceuticals companies are founded and created by one or a group of scientists with secondary education level (Bachelor of science in physics, chemical, biology etc.), but, they may not desire to become CEO. They will appoint external professional at latter stage of lifecycle. It should be noted that there is a lot of new appointment on the CEO chair, and this new people are predominantly insiders with previous experience in the industry with high education level with three or four degree (B.S, M.D., MBA, PhD). And others are founders, which either at once became CEO or after few years, and they have not so much educational experience (only B.A. or B.S.). Mr. Vivek Ramaswamy is the Founder of Roivant Sciences, Inc. and serves as its Chief Executive Officer since March 2015, and has a A.B. in Biology. And a counterexample: Dr. Martine A. Rothblatt, Ph.D., MBA, J.D., Founded United Therapeutics Corporation in 1996, and has been its Chief Executive Officer since June 26, 2016 and as its Chairman since 1996. That is why tenure is also negatively associated with firm performance. There is a high impact of CEO-founder on ROA and ROE. This result confirms conclusions conducted on the large panel of US IT companies in recent paper of Chiu, Chen, Cheng, Hung (2019) [45]. Alike the authors we show that CEO-founder have more power, which lowers agency costs and enhances long-term firm performance. Pharmaceutical business is entrepreneurial business, which frequently further transform into the family business. As opposed to Hardware \& Equipment industry, with the least number of CEO-founders, (except Facebook, Apple and Google), tenure and educational degree are highly significant (at 5\%) for firm performance.

Interestingly, the presence of male $\mathrm{CEO}$ increases firm profitability in this sector, which is explained by prevalence of male members. However, this result cannot be treated as a robust result, since there is only one female CEO among 121 companies. Ms. Cheryl Podzimek Beranek, also known as Cheri, has been the Chief Executive Officer and President at Clearfield, Inc. since June 28, 2007. 
Table 1. CEO characteristics and technological firm performance

\begin{tabular}{|c|c|c|c|c|c|c|c|c|}
\hline \multirow[b]{2}{*}{ VARIABLES } & \multicolumn{2}{|c|}{ Software \& Services } & \multicolumn{3}{|c|}{ Pharmaceuticals, Biotechnology \& Life Sciences } & \multicolumn{3}{|c|}{ Technology Hardware \& Equipment } \\
\hline & Tobin Q & ROA & Tobin Q & ROE & ROA & Tobin Q & ROE & ROA \\
\hline \multirow{2}{*}{ Degree } & -0.0242 & 0.0484 & $-0.112^{*}$ & 1.316 & $1.556^{* *}$ & $0.176^{* * *}$ & $1.881^{*}$ & $0.826^{*}$ \\
\hline & $(0.0445)$ & $(0.395)$ & $(0.0610)$ & $(1.248)$ & $(0.743)$ & $(0.0552)$ & $(0.972)$ & $(0.496)$ \\
\hline \multirow{2}{*}{ Founder } & -0.0171 & $0.216^{*}$ & -0.0214 & $0.882^{* *}$ & $0.721^{* * *}$ & $-0.0222^{*}$ & -0.0834 & -0.0805 \\
\hline & $(0.0133)$ & $(0.118)$ & $(0.0209)$ & $(0.445)$ & $(0.260)$ & $(0.0131)$ & $(0.234)$ & $(0.120)$ \\
\hline \multirow{2}{*}{ Tenure } & 0.00659 & -0.159 & 0.00265 & $-1.074^{* *}$ & $-0.671^{\star * *}$ & -0.00149 & $0.547^{\star *}$ & $0.235^{\star *}$ \\
\hline & $(0.0134)$ & $(0.120)$ & $(0.0201)$ & $(0.440)$ & $(0.245)$ & $(0.0129)$ & $(0.230)$ & $(0.118)$ \\
\hline \multirow{2}{*}{ Gender } & $0.483^{*}$ & 2.733 & 0.256 & 3.899 & 6.127 & -0.344 & 2.791 & $5.257^{*}$ \\
\hline & $(0.295)$ & $(2.598)$ & $(0.349)$ & $(6.836)$ & $(4.246)$ & $(0.343)$ & $(5.929)$ & $(2.896)$ \\
\hline \multirow{2}{*}{ Board Size } & -0.0506 & $-0.663^{*}$ & 0.0386 & 0.448 & -0.925 & $-0.0732^{\star \prime}$ & $-1.292^{*}$ & -0.310 \\
\hline & $(0.0510)$ & $(0.452)$ & $(0.0623)$ & $(1.247)$ & $(0.783)$ & $(0.0469)$ & $(0.837)$ & $(0.418)$ \\
\hline \multirow{2}{*}{ Women \% } & $0.0290^{* * *}$ & $-0.228^{* * *}$ & 0.0138 & 0.0903 & 0.0758 & $-0.0207^{* *}$ & -0.163 & -0.0300 \\
\hline & $(0.00843)$ & $(0.0746)$ & $(0.0111)$ & $(0.229)$ & $(0.137)$ & $(0.00893)$ & $(0.155)$ & $(0.0788)$ \\
\hline \multirow{2}{*}{ Independent $\mathrm{D} \%$} & -0.00351 & 0.0704 & $-0.0205^{\star *}$ & 0.0996 & 0.0156 & -0.00168 & 0.109 & -0.0333 \\
\hline & $(0.00689)$ & $(0.0609)$ & $(0.00985)$ & $(0.198)$ & $(0.115)$ & $(0.00657)$ & $(0.119)$ & $(0.0603)$ \\
\hline \multirow{2}{*}{ Firm Size } & $-0.612^{* * *}$ & $3.062^{* * *}$ & $-0.727^{* * *}$ & $21.19^{* * *}$ & $12.29^{* * *}$ & $-0.209^{* *}$ & $6.482^{* * *}$ & $2.388^{* * *}$ \\
\hline & $(0.100)$ & $(0.883)$ & $(0.0958)$ & $(2.022)$ & $(1.202)$ & $(0.0985)$ & $(1.679)$ & $(0.794)$ \\
\hline \multirow{2}{*}{$\mathrm{R} \& \mathrm{D}$} & $0.456^{* * *}$ & -0.385 & $0.575^{\star * *}$ & $-8.957^{* * *}$ & -1.768 & 0.0540 & -2.324 & -0.160 \\
\hline & $(0.0803)$ & $(0.711)$ & $(0.0970)$ & $(1.993)$ & $(1.242)$ & $(0.0813)$ & $(1.461)$ & $(0.717)$ \\
\hline
\end{tabular}




\begin{tabular}{|c|c|c|c|c|c|c|c|c|}
\hline \multirow[b]{2}{*}{ VARIABLES } & \multicolumn{2}{|c|}{ Software $\&$ Services } & \multicolumn{3}{|c|}{ Pharmaceuticals, Biotechnology \& Life Sciences } & \multicolumn{3}{|c|}{ Technology Hardware \& Equipment } \\
\hline & Tobin Q & ROA & Tobin Q & ROE & ROA & Tobin Q & ROE & ROA \\
\hline \multirow{2}{*}{ Leverage } & $-0.0176^{* * *}$ & $0.119^{* * *}$ & $-0.0145^{\star * \star}$ & -0.0741 & 0.0367 & $-0.00547^{\star *}$ & $0.146^{* * *}$ & $0.0403^{*}$ \\
\hline & $(0.00449)$ & $(0.0398)$ & $(0.00376)$ & $(0.0741)$ & $(0.0486)$ & $(0.00229)$ & $(0.0412)$ & $(0.0207)$ \\
\hline \multirow{2}{*}{ Company Age } & $-0.00831^{\star *}$ & $-0.0468^{\star \prime}$ & 0.00398 & $-0.238^{* * *}$ & -0.0487 & -0.00292 & $-0.493^{* * *}$ & $-0.202^{* * *}$ \\
\hline & $(0.00366)$ & $(0.0319)$ & $(0.00346)$ & $(0.0903)$ & $(0.0425)$ & $(0.00388)$ & $(0.0776)$ & $(0.0343)$ \\
\hline \multirow{2}{*}{ Growth of Sales } & $1.402^{* * *}$ & -2.218 & & & $5.201^{\star *}$ & $0.918^{\star * *}$ & -5.570 & \\
\hline & $(0.279)$ & $(2.408)$ & & & $(2.526)$ & $(0.255)$ & $(4.467)$ & \\
\hline \multirow{2}{*}{ Vol.3 EBITDA } & 0.000585 & 0.00366 & & & $-0.0166^{\star}$ & $0.00112^{\star \star}$ & & \\
\hline & $(0.000452)$ & $(0.00400)$ & & & $(0.00864)$ & $(0.000459)$ & & \\
\hline \multirow{2}{*}{ Constant } & $5.803^{* * *}$ & $-21.57^{\star * \star}$ & $7.887^{\star * *}$ & $-133.5^{\star * *}$ & $-94.32^{* * *}$ & $4.557^{\star * *}$ & $-32.09^{* * *}$ & $-12.82^{\star *}$ \\
\hline & $(0.691)$ & $(6.100)$ & $(0.958)$ & (19.46) & $(11.92)$ & $(0.716)$ & (12.25) & $(5.951)$ \\
\hline Observations & 429 & 437 & 467 & 410 & 464 & 301 & 300 & 317 \\
\hline R-squared & 0.297 & 0.141 & 0.234 & 0.362 & 0.377 & 0.242 & 0.218 & 0.188 \\
\hline Number of Firms & 124 & 119 & 124 & 130 & 115 & 125 & 74 & 74 \\
\hline
\end{tabular}


Table 2. Investor type, $\mathrm{CEO}$ characteristics and firm performance

Software \& Services Pharmaceuticals, Biotechnology \& Life Sciences

\section{VARIABLES}

Top 5 Strategic

Top5 Grey (active)

Top5 Independent (active)

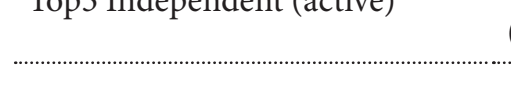

\section{ROA}

$$
-0.0690
$$

$(0.0541)$

$-0.465$

(0.439)

0.0744

(0.0719)

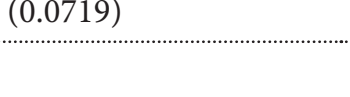

\section{Tobin Q}

ROE

$-0.0233^{\star *}$

$(0.0111)$

$-0.103$

(0.0971)

$-0.00890$

$(0.00777)$

$0.0433^{* *}$

$(0.0184)$

Top5 Independent (passive)

\begin{tabular}{|c|c|c|c|c|c|c|c|}
\hline & & & & & & & $(0.135)$ \\
\hline \multirow{2}{*}{ Degree } & 0.0550 & $-0.147^{\star \star}$ & $2.026^{\star \prime}$ & $1.877^{\star \star}$ & $0.165^{\star \star *}$ & $2.026^{\star *}$ & $0.944^{* *}$ \\
\hline & $(0.391)$ & $(0.0624)$ & $(1.287)$ & $(0.740)$ & $(0.0535)$ & $(0.968)$ & $(0.472)$ \\
\hline \multirow{2}{*}{ Founder } & $0.253^{\star *}$ & -0.0199 & 0.649 & $0.717^{\star * *}$ & -0.0165 & 0.0165 & -0.0663 \\
\hline & $(0.120)$ & $(0.0214)$ & $(0.457)$ & $(0.254)$ & $(0.0132)$ & $(0.237)$ & $(0.116)$ \\
\hline \multirow{2}{*}{ Tenure } & -0.162 & 0.00570 & $-0.849^{\star}$ & $-0.641^{* * *}$ & -0.00495 & $0.431^{\star}$ & $0.261^{\star *}$ \\
\hline & $(0.120)$ & $(0.0206)$ & $(0.450)$ & $(0.241)$ & $(0.0130)$ & $(0.232)$ & $(0.114)$ \\
\hline \multirow{2}{*}{ Gender } & 3.376 & 0.296 & 5.145 & $5.989^{*}$ & -0.253 & 3.382 & $6.131^{* *}$ \\
\hline & $(2.607)$ & $(0.352)$ & $(6.937)$ & $(4.163)$ & $(0.329)$ & (5.879) & $(2.823)$ \\
\hline \multirow{2}{*}{ Board Size } & -0.601 & $0.104^{\star \prime}$ & -0.0657 & $-1.282^{\star \prime}$ & $-0.0946^{\star *}$ & $-1.590^{\star}$ & -0.432 \\
\hline & $(0.447)$ & $(0.0656)$ & $(1.321)$ & $(0.789)$ & $(0.0466)$ & $(0.835)$ & $(0.409)$ \\
\hline
\end{tabular}


Software \& Services $\quad$ Pharmaceuticals, Biotechnology \& Life Sciences

\begin{tabular}{|c|c|c|c|c|c|c|c|}
\hline VARIABLES & ROA & Tobin Q & ROE & ROA & Tobin Q & ROE & ROA \\
\hline \multirow{2}{*}{ Women \% } & $-0.223^{* * *}$ & 0.00909 & 0.164 & 0.137 & $-0.0197^{\star *}$ & -0.210 & -0.0325 \\
\hline & $(0.0742)$ & $(0.0115)$ & $(0.240)$ & $(0.137)$ & $(0.00864)$ & $(0.155)$ & $(0.0755)$ \\
\hline \multirow{2}{*}{ Independent D\% } & 0.0122 & $-0.0150^{\star ’}$ & -0.0863 & -0.0288 & 0.00360 & $0.210^{*}$ & -0.0260 \\
\hline & $(0.0671)$ & $(0.0104)$ & $(0.214)$ & $(0.117)$ & $(0.00702)$ & $(0.129)$ & $(0.0624)$ \\
\hline \multirow{2}{*}{ Firm Size } & $3.415^{* * *}$ & $-0.759^{* * *}$ & $19.90^{* * *}$ & $11.89^{* * *}$ & $-0.180^{*}$ & $5.684^{* * *}$ & $1.524^{*}$ \\
\hline & $(0.863)$ & $(0.101)$ & $(2.136)$ & $(1.184)$ & $(0.0926)$ & $(1.683)$ & $(0.812)$ \\
\hline \multirow{2}{*}{$\mathrm{R} \& \mathrm{D}$} & -0.293 & $0.548^{* * *}$ & $-8.196^{\star * *}$ & $-2.483^{* *}$ & $0.152^{\star}$ & -1.498 & 0.609 \\
\hline & $(0.707)$ & $(0.0991)$ & $(2.056)$ & $(1.179)$ & $(0.0820)$ & $(1.506)$ & $(0.714)$ \\
\hline \multirow{2}{*}{ Leverage } & $0.108^{* * *}$ & $-0.0158^{* * *}$ & -0.0666 & 0.0217 & $-0.00465^{\star *}$ & $0.165^{* * *}$ & $0.0450^{* *}$ \\
\hline & $(0.0379)$ & $(0.00381)$ & $(0.0757)$ & $(0.0461)$ & $(0.00230)$ & $(0.0414)$ & $(0.0196)$ \\
\hline \multirow{2}{*}{ Company Age } & $-0.0545^{\star}$ & 0.00372 & $-0.217^{\star *}$ & $-0.0602^{\star}$ & -0.00181 & $-0.481^{\star * \star}$ & $-0.173^{\star * *}$ \\
\hline & $(0.0322)$ & $(0.00368)$ & $(0.0971)$ & $(0.0427)$ & $(0.00388)$ & $(0.0770)$ & $(0.0331)$ \\
\hline \multirow{2}{*}{ Growth of Sales } & -1.633 & 0.00520 & 2.541 & $5.466^{* *}$ & $0.868^{* * *}$ & -6.702 & -0.511 \\
\hline & $(2.385)$ & $(0.213)$ & $(4.688)$ & $(2.515)$ & $(0.254)$ & $(4.444)$ & $(2.174)$ \\
\hline \multirow{2}{*}{ Constant } & $-20.71^{\star * \star}$ & $7.579^{* * *}$ & $-108.3^{\star * *}$ & $-86.80^{\star * \star}$ & $3.848^{\star * *}$ & $-34.12^{* *}$ & $-16.64^{\star * *}$ \\
\hline & $(6.480)$ & $(1.051)$ & $(21.93)$ & $(11.88)$ & $(0.729)$ & $(13.33)$ & $(6.234)$ \\
\hline Observations & 444 & 449 & 393 & 472 & 305 & 300 & 310 \\
\hline R-squared & 0.142 & 0.238 & 0.335 & 0.381 & 0.256 & 0.243 & 0.240 \\
\hline Number of Firms & 124 & 120 & 106 & 127 & 75 & 74 & 75 \\
\hline
\end{tabular}


Also, CEO's tenure was found significant for Pharmaceutical and Technology industries. However, the influence of tenure differs among these industries. In Pharmaceutical companies, tenure have a negative influence on firm performance, measured by ROE and ROA. We suggest that CEO with higher tenure in this industry, while accumulations knowledge over the years can become entrenched, and, subsequently, will try to avoid losses over pursuing gains (Luo, Kanuri, Andrews, 2013 [46]). On the other hand, CEO's tenure in Technology Hardware industry seems to positively affect ROE, ROA. This result supports the view of Gunasekarage, Luong, Truong (2019) [47], that CEOs with a longer tenure could form such management structure, which will enhance firm performance.

Then, our next step is to analyze CEO characteristics in interference with different investor types (Table 2). For Software \& Services industry we found out that CEO-Founder, which previously was not significant (Table 1), positively influence on ROA by outweighing impact of active independent investor type of firm performance. A similar effect is observable for Biotechnology industry, where in ROA specification Top 5 active independent investors (previously with negative sign) became positive, but the significance of all other investors disappears. When founder, degree and tenure become significant, investor's type becomes insignificant or change its sign. More surprisingly, degree preserve its positive sign, and all previous results for Top5 Independent investors are conserved. This mean, that these CEO characteristics and investor's type are highly important for this sector. Thus, we verify stability of influence of both investor's type and CEO characteristics on firm performance.

\section{Conclusion}

In this paper we develop a hypothesis of complement influence of CEO characteristics on firm performance of technology companies. We contribute to the research of corporate governance and performance drivers in technology sectors. The finding suggests that such CEO characteristics as tenure, degree and is he/she a founder are important in Pharmaceuticals and Hardware industries, with high impact on firm profitability. These results are similar to those obtained by Lee, Kim, Bae (2020) [48], where CEO-founder generate more explorative innovations. We find the evidence that educational degree has a positive influence on firm profitability in both hardware and biotechnological sectors. This result is in line with previous results of Jiménez-Jiménez et al. (2011) [18] study. At the same time, we show that the market dislikes the situations when the biotechnological companies are managed by highly educated CEOs. We do believe that in biotechnology companies investors prefer the entrepreneurs and professional managers at the CEO position to the professors heading the research team. However, we found a positive relationship between tenure of CEO and firm performance for Technology Hardware industry (in line with Gunasekarage, Luong, Truong 2019 [47]), which contradicts to the result obtained for Pharmaceutical companies. In addition, we found practically no evidence concerning the board independence and ownership structure of innovative firms, that contradicts to the results on the role of independent directors received by Chen et al. (2016) [15].

This study contributes to the existing literature in two aspects. First, our findings indicate that CEO characteristics play crucial roles in explaining technology firm value and performance. We demonstrated that founding CEO contributes to technology firm performance as well as the CEO with better education. Some scholars found that powerful CEO lead to poor performance (Han, Nanda, Silveri, 2016 [49]), however, we found that powerful and smart CEOs can contribute to better performance and stronger survivability as Chiu, Chen, Cheng, Hung (2019) [45]. Second, CEOs should be smart and powerful in order to sustain firm performance. We found that CEOs characteristics mitigate the conflicts between different types of investors and their influence on firm performance.

There is a number of practical implications of this study. First of all, we conducted our analysis on a large sample of US firms, taking into account more than $98 \%$ of US capital market. Secondly, we used a new procedure of scaled degree test for CEO characteristics, which was not previously tested on US market. Thirdly, we supplement the presented results by real examples of the sample, that prove the validity of our research.

For future studies, we provide an opportunity to test a nonlinear relationship between CEO characteristics discussed above and firm performance. We suggest to add in future research CEO power index, measured following Lee, Kim, Bae (2020) [48], as a dummy variable that equals 1 when the CEO is the founder, has duality, or is an insider. It is also important to take into account risk preferences of the CEO, which should also influence the firm performance (Anilov, Ivashkovskaya, 2019 [50]). We also reveal the importance to further analyze the board diversity in educational and professional background.

\section{References}

1. Fu Y. Independent directors, CEO career concerns, and firm innovation: Evidence from China. The North American Journal of Economics and Finance. 2019;50:101037. DOI: 10.1016/j.najef.2019.101037

2. Sheikh $\mathrm{S}$. The impact of market competition on the relation between CEO power and firm innovation. Journal of Multinational Financial Management. 2018;44:36-50. DOI: 10.1016/j.mulfin.2018.01.003

3. Cho S.Y., Kim S.K. Horizon problem and firm innovation: The influence of CEO career horizon, exploitation and exploration on breakthrough innovations. Research Policy. 2017;46:1801-1809. DOI: 10.1016/j.respol.2017.08.007 
4. Sunder J., Sunder S.V., Zhang J. Pilot CEOs and corporate innovation. Journal of Financial Economics. 2017;123(1):209-224. DOI: 10.1016/j. jfineco.2016.11.002

5. Han S. CEO political preference and corporate innovation. Finance Research Letters. 2019;28:370375. DOI: 10.1016/j.frl.2018.06.006

6. Jung (Henny) H.W., Subramanian A. CEO talent, CEO compensation, and product market competition. Journal of Financial Economics. 2017;125(1):48-71. DOI: 10.1016/j. jineco.2017.04.005

7. Zhang H., Ou A.Y., Tsui A.S., Wang H. CEO humility, narcissism and firm innovation: A paradox perspective on CEO traits. The Leadership Quarterly. 2017;28(5):585-604. DOI: 10.1016/j. leaqua.2017.01.003

8. Makri M., Scandura T. Exploring the effects of creative CEO leadership on innovation in hightechnology firms. The Leadership Quarterly. 2010;21(1):75-88. DOI: 10.1016/j.leaqua.2009.10.006

9. Lin C., Lin P., Song F., Li C. Managerial incentives, CEO characteristics and corporate innovation in China's private sector. Journal of Comparative Economics. 2011;39(2):176-190. DOI: 10.1016/j. jce.2009.12.001

10. Karnoukhova E., Stepanova A., Kokoreva M. The influence of the ownership structure on the performance of innovative companies in the US. SSRN Electronic Journal. 2018. DOI: 10.2139/ ssrn.3287670

11. Baysinger B.D., Kosnik R.D., Turk T.A. Effects of board and ownership structure on corporate R\&D strategy. The Academy of Management Journal. 1991;34(1):205-214. DOI: $10.2307 / 256308$

12. Hoskisson R.E., Hitt M.A., Johnson R.A., Grossman W. Conflicting voices: The effects of institutional ownership heterogeneity and internal governance on corporate innovation strategies. The Academy of Management Journal. 2002;45(4):697-716. DOI: $10.2307 / 3069305$

13. De Cleyn S., Braet J. Do board composition and investor type influence innovativeness in SMEs? International Entrepreneurship and Management Journal. 2012;8(3):285-308. DOI: 10.1007/s11365010-0168-6

14. Rafiq S., Salim R., Smyth R. The moderating role of firm age in the relationship between $R \& D$ expenditure and financial performance: Evidence from Chinese and US mining firms. Economic Modelling. 2016;56:122-132. DOI: 10.1016/j. econmod.2016.04.003

15. Chen C-J., Lin B-W., Lin Y-H., Hsiao Y-C. Ownership structure, independent board members and innovation performance: A contingency perspective. Journal of Business
Research. 2016;69(9):3371-3379. DOI: 10.1016/j. jbusres.2016.02.007

16. Talaja A. Innovative capabilities, firm performance and foreign ownership: Empirical analysis of large and medium-sized companies form all industries. Business and Economic Horizons. 2013;9(3):69-78. DOI: 10.15208/beh.2013.14

17. Hull C.E., Rothenberg S. Firm performance: the interactions of corporate social performance with innovation and industry differentiation. Strategic Management Journal. 2008;29(7):781-789. DOI: 10.1002/smj.675

18. Jiménez-Jiménez D., Sanz-Valle R. Innovation, organizational learning, and performance. Journal of Business Research. 2011;64(4):408-417. DOI: 10.1016/j.jbusres.2010.09.010

19. Eriksson T., Qin Z., Wang W. Firm-level innovation activity, employee turnover and HRM practices - Evidence from Chinese firms. China Economic Review. 2014;30:583-597. DOI: 10.1016/j. chieco.2014.02.005

20. Héroux S., Fortin A. Innovation: The influence of diversity and it competence of boards of directors and executive management. The International Journal of Organizational Innovation. 2016;8(3):18-43.

21. Gavious I., Hirsh N., Kaufman D. Innovation in pyramidal ownership structures. Finance Research Letters. 2015;13:188-195. DOI: 10.1016/j. frl.2015.01.004

22. Hsu C.-H., Lai S.-C., Li H.-C. Institutional ownership and information transparency: Role of technology intensities and industries. Asia Pacific Management Review. 2016;21(1):26-37. DOI: 10.1016/j. apmrv.2015.06.001

23. Colombo M.G., Croce A., Murtinu S. Ownership structure, horizontal agency costs and the performance of high-tech entrepreneurial firms. Small Business Economics. 2014;42(2):265-282. DOI: 10.1007/s11187-013-9483-y

24. Chi C.W., Lieu P.T., Hung K., Cheng H.W. Do industry or firm effects drive performance in Taiwanese knowledge-intensive industries? Asia Pacific Management Review. 2016;21(3):170-179. DOI: 10.1016/j.apmrv.2016.05.001

25. Knyazeva A., Knyazeva D., Masulis R.W. The supply of corporate directors and board independence. The Review of Financial Studies. 2013;26(6):1561-1605. DOI: $10.1093 / \mathrm{rfs} / \mathrm{hht} 020$

26. Balsmeier B., Buchwald A., Stiebale J. Outside directors on the board and innovative firm performance. Research Policy. 2014;43(10):1800-1815. DOI: 10.1016/j.respol.2014.06.003

27. Boasson V., Boasson E. Firm value, spatial knowledge flow, and innovation: Evidence from patent citations. China Finance Review International. 2015;5(2):132160. DOI: 10.1108/CFRI-08-2014-0056 
28. Tereshchenko A., Stepanova A. The influence of independent directors, insider ownership and scientific connections on risky R\&D investments: Evidence from emerging markets. Korporativnye finansy = Journal of Corporate Finance Research. 2016;10(3):5-23. DOI: 10.17323/j.jcfr.20730438.10.3.2016.5-23

29. Kang K.-N., Park H. Influence of government $\mathrm{R} \& \mathrm{D}$ support and inter-firm collaborations on innovation in Korean biotechnology SMEs. Technovation. 2012;32(1):68-78. DOI: 10.1016/j. technovation.2011.08.004

30. Crane A., Michenaud S., Weston J. The effect of institutional ownership on payout policy: Evidence from index thresholds. The Review of Financial Studies. 2016;29(6):1377-1408. DOI: 10.1093/rfs/ hhw012

31. Appel I.R., Gormley T.A., Keim D.B. Passive investors, not passive owners. Journal of Financial Economics. 2016;121(1):111-141. DOI: 10.1016/j. jineco.2016.03.003

32. Chen H.-L. Board capital, CEO power and $\mathrm{R} \& \mathrm{D}$ investment in electronics firms. Corporate Governance: An International Review. 2014;22(5):422436. DOI: $10.1111 /$ corg. 12076

33. Shan Y.G., McIver R.P. Corporate governance mechanisms and financial performance in China: Panel data evidence on listed non financial companies. Asia Pacific Business Review. 2011;17(3):301-324. DOI: $10.1080 / 13602380903522325$

34. Li K., Lu L., Mittoo U.R., Zhang Z. Board independence, ownership concentration and corporate performance - Chinese evidence. International Review of Financial Analysis. 2015;41:162-175. DOI: 10.1016/j.irfa.2015.05.024

35. Cornett M.M., Marcus A.J., Saunders A., Tehranian $H$. The impact of institutional ownership on corporate operating performance. Journal of Banking \& Finance. 2007;31(6):1771-1794. DOI: 10.1016/j. jbankfin.2006.08.006

36. Darmadi S. Board members' education and firm performance: Evidence from a developing economy. International Journal of Commerce and Management. 2013;23(2):113-135. DOI: 10.1108/10569211311324911

37. Chiang H.-T., Lin S.-L., He L.-J., Sung Y.-T. Professional education background and earnings management of chairmen and senior managers. The International Journal of Business and Finance Research. 2016;10(2):91-108. URL: http://www. theibfr2.com/RePEc/ibf/ijbfre/ijbfr-v10n2-2016/ IJBFR-V10N2-2016-7.pdf

38. Barker V.L., Mueller G.C. CEO characteristics and firm R\&D spending. Management Science. 2002;48(6):782-801. DOI: 10.1287/mnsc.48.6.782.187
39. Terjesen S.C., Couto E.B., Francisco P.M. Does the presence of independent and female directors impact firm performance? A multi-country study of board diversity. Journal of Management \& Governance. 2016;20(3):447-483. DOI 10.1007/ s10997-014-9307-8

40. McConnell J.J., Servaes H. Additional evidence on equity ownership and corporate value. Journal of Financial Economics. 1990;27(2):595-612. DOI: 10.1016/0304-405X(90)90069-C

41. Lin Y.R., Fu X.M. Does institutional ownership influence firm performance? Evidence from China. International Review of Economics \& Finance. 2017;49:17-57. DOI: 10.1016/j.iref.2017.01.021

42. De-la-Hoz M.C., Carlos P. Institutional investor heterogeneity and firm valuation: Evidence from Latin America. Emerging Markets Review. 2016;26:197-221. DOI: 10.1016/j. ememar.2015.12.001

43. Acharya V., Xu Z. Financial dependence and innovation: The case of public versus private firms. Journal of Financial Economics. 2017;124(2):223-243. DOI: 10.1016/j.jfineco.2016.02.010

44. Nashier T., Gupta A. The effect of institutional ownership on firm performance. IUP Journal of Corporate Governance. 2016;15(3):36-56.

45. Chiu J., Chen C., Cheng C.-C., Hung S. Knowledge capital, CEO power, and firm value: Evidence from the IT industry. The North American Journal of Economics and Finance. 2019;(101012). DOI: 10.1016/j.najef.2019.101012

46. Luo X., Kanuri V.S., Andrews M. Long CEO tenure can hurt performance. Harvard Business Review. 2013;(March). URL: https://hbr.org/2013/03/longceo-tenure-can-hurt-performance

47. Gunasekarage A., Luong H., Truong T.T. Growth and market share matrix, CEO power, and firm performance. Pacific-Basin Finance Journal. 2019;(101257). DOI: 10.1016/j.pacfin.2019.101257

48. Lee J.M., Kim J., Bae J. Founder CEOs and innovation: Evidence from CEO sudden deaths in public firms. Research Policy. 2020;49(1):103862. DOI: 10.1016/j.respol.2019.103862

49. Han S., Nanda V.K., Silveri S. CEO power and firm performance under pressure. Financial Management. 2016;45(2):369-400. DOI: 10.1111/fima.12127

50. Anilov A., Ivashkovskaya I. Do boards of directors affect $\mathrm{CEO}$ behavior? Evidence from payout decisions. Journal of Management and Governance. 2019. DOI: 10.1007/s10997-019-09491-Z 


\section{Appendix}

\section{Table 1. Descriptive statistics}

\begin{tabular}{|c|c|c|c|c|c|}
\hline Variable & Observation & Mean & Std. Dev. & Min & $\operatorname{Max}$ \\
\hline \multicolumn{6}{|c|}{ Dependent variables } \\
\hline Tobin $Q$ & 9213 & 2.482678 & 1.709054 & .8939 & 8.4492 \\
\hline ROE & 8724 & 6.145749 & 19.43469 & -36.649 & 29.895 \\
\hline$R O A$ & 9703 & -2.045606 & 22.22631 & -83.7228 & 23.8757 \\
\hline \multicolumn{6}{|c|}{ Independent variables } \\
\hline Top 5 Grey (active) & 12564 & .3563451 & 2.385981 & 0 & 66.984 \\
\hline Top 5 Grey (not active/passive) & 12564 & .547063 & 3.438737 & 0 & 68.372 \\
\hline Top 5 Independent (active) & 12564 & 8.905715 & 11.64401 & 0 & 163.879 \\
\hline Top 5 Independent (not active/passive) & 12564 & 2.854993 & 5.254732 & 0 & 82.272 \\
\hline Top 5 Independent (passive) & 12564 & 4.043734 & 5.890471 & 0 & 66.533 \\
\hline Top5 Strategic & 12564 & 8.656271 & 16.73545 & 0 & 164.624 \\
\hline Top5 State & 12564 & 1.016903 & 6.183102 & 0 & 92.296 \\
\hline Board Size & 5873 & 8.805158 & 2.241266 & 1 & 19 \\
\hline Women on Board (\%) & 5851 & 11.15278 & 10.14136 & 0 & 71.429 \\
\hline Independent Director (\%) & 5827 & 77.87007 & 12.23409 & 44.444 & 91.67 \\
\hline Leverage & 10182 & 23.03372 & 26.65251 & 0 & 106.59 \\
\hline
\end{tabular}




\begin{tabular}{|c|c|c|c|c|c|}
\hline Variable & Observation & Mean & Std. Dev. & Min & $\operatorname{Max}$ \\
\hline Firm Size & 10026 & 6.726709 & 1.820372 & 2.911823 & 10.60352 \\
\hline$R \& D$ & 5967 & 3.616425 & 1.832616 & .1823216 & 8.108322 \\
\hline Company Age & 12480 & 42.05329 & 37.88536 & 3 & 145 \\
\hline growth of Sales & 9115 & .1627667 & .3276786 & -.3836548 & 1.484608 \\
\hline Vol. 3 EBITDA & 8119 & 83.11091 & 167.5665 & 1.181395 & 847.2207 \\
\hline Tenure & 7332 & 6.615248 & 7.316767 & 0 & 50 \\
\hline Founder & 1966 & .9389624 & .2394603 & 0 & 1 \\
\hline Gender & 9536 & .9365562 & .2437722 & 0 & 1 \\
\hline Degree & 7334 & 2.653941 & 1.645846 & 0 & 8 \\
\hline
\end{tabular}




\section{Table 2. CEO characteristic}

\begin{tabular}{|c|c|c|c|c|c|c|c|c|c|c|c|c|c|c|c|}
\hline \multirow[b]{2}{*}{ Variable } & \multicolumn{5}{|c|}{ Software \& Services } & \multicolumn{5}{|c|}{ Pharmaceuticals, Biotechnology \& Life Sciences } & \multicolumn{5}{|c|}{ Technology Hardware \& Equipment } \\
\hline & Obs & Mean & Std.Dev. & Min & Max & Obs & Mean & Std.Dev. & Min & Max & Obs & Mean & Std.Dev. & Min & $\operatorname{Max}$ \\
\hline Founder & 1049 & .8856053 & .3184418 & 0 & 1 & 725 & 1 & 0 & 0 & 1 & 192 & 1 & 0 & 0 & 1 \\
\hline Gender & 2104 & .9477186 & .2226468 & 0 & 1 & 2470 & .9076923 & .2895184 & 0 & 1 & 1075 & .9572093 & .2024791 & 0 & 1 \\
\hline Degree & 2898 & 2.358178 & 1.624822 & 0 & 8 & 2998 & 3.178119 & 1.636757 & 0 & 8 & 1438 & 2.157163 & 1.384495 & 0 & 6 \\
\hline Tenure & 2898 & 7.704279 & 7.569208 & 0 & 36 & 4336 & 7.346402 & 7.636006 & 0 & 36 & 1438 & 6.625174 & 7.721265 & 0 & 35 \\
\hline Bachelor of Arts & 1344 & .9308036 & .2538823 & 0 & 1 & 1032 & 1 & 0 & 1 & 1 & 302 & 1 & 0 & 1 & 1 \\
\hline Bachelor of Science & 1479 & .9546991 & .257453 & 0 & 2 & 1318 & 1 & 0 & 1 & 1 & 920 & 1 & 0 & 1 & 1 \\
\hline Master & 1079 & 2 & 0 & 2 & 2 & 1140 & 1.936842 & .2433535 & 1 & 2 & 229 & 1.947598 & .223324 & 1 & 2 \\
\hline$M B A$ & 621 & 1.961353 & .2755419 & 0 & 2 & 1018 & 2.011788 & .107983 & 2 & 3 & 483 & 2 & 0 & 2 & 2 \\
\hline$P h D$ & 144 & 3 & 0 & 3 & 3 & 755 & 2.968212 & .1755517 & 2 & 3 & 132 & 3 & 0 & 3 & 3 \\
\hline$J D$ & 157 & 3 & 0 & 3 & 3 & 227 & 3 & 0 & 3 & 3 & 24 & 3 & 0 & 3 & 3 \\
\hline Business & 565 & 1 & 0 & 1 & 1 & 240 & 1 & 0 & 1 & 1 & 216 & 1 & 0 & 1 & 1 \\
\hline Engineering & 416 & 1 & 0 & 1 & 1 & 245 & 1 & 0 & 1 & 1 & 643 & 1 & 0 & 1 & 1 \\
\hline Economics & 360 & 1 & 0 & 1 & 1 & 216 & 1 & 0 & 1 & 1 & 134 & 1 & 0 & 1 & 1 \\
\hline Accounting & 107 & 1 & 0 & 1 & 1 & 108 & 1 & 0 & 1 & 1 & 84 & 1 & 0 & 1 & 1 \\
\hline Law & 120 & 1 & 0 & 1 & 1 & 24 & 1 & 0 & 1 & 1 & 24 & 1 & 0 & 1 & 1 \\
\hline Computer Science & 541 & 1 & 0 & 1 & 1 & 24 & 1 & 0 & 1 & 1 & 108 & 1 & 0 & 1 & 1 \\
\hline $\begin{array}{l}\text { Humanitarian Sci- } \\
\text { ence }\end{array}$ & 180 & 1 & 0 & 1 & 1 & 97 & 1 & 0 & 1 & 1 & 24 & 1 & 0 & 1 & 1 \\
\hline Natural Science & 57 & 1 & 0 & 1 & 1 & 852 & 1.014085 & .1179087 & 1 & 2 & 24 & 1 & 0 & 1 & 1 \\
\hline Medical Doctor & 0 & & & & & 701 & 1 & 0 & 1 & 1 & 0 & & & & \\
\hline
\end{tabular}


Table 3. Definition of variables

Dependent variables

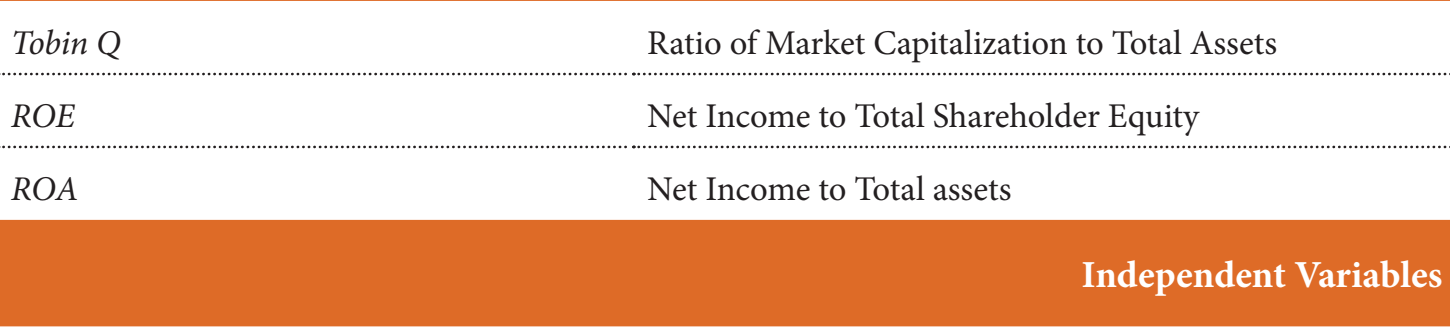

Ownership structure

Independent Institutions

Grey Institutions

Top 5 Grey (active)

Top 5 Grey (not active/passive)

Top 5 Independent (active)

Top 5 Independent (not active/passive)

Top 5 Independent (passive)

Top5 Strategic

Top5 State
Institutional ownership held by independent institutions (traditional Investment Managers, Hedge Funds Managers) as a percentage of market capitalization

Institutional ownership held by grey institutions (Banks, Pension Funds, Educational/Cultural Endowments, Insurance companies, REITs, Family Offices trusts) as a percentage of market capitalization

The percentage of corporate shares held by first five grey institutions with active strategy (Banks, Educational/Cultural Endowments, Family Offices trusts)

The percentage of corporate shares held by first five grey institutions with not active/passive strategy (Banks, Educational/Cultural Endowments, Family Offices trusts, Insurance Companies, Pension Funds, REITs)

The percentage of corporate shares held by first five independent institutions with active strategy (Traditional Investment Managers, Hedge Funds Managers)

The percentage of corporate shares held by first five independent institutions with not active/passive strategy (Traditional Investment Managers, Hedge Funds Managers)

The percentage of corporate shares held by first five independent institutions with passive strategy (Traditional Investment Managers)

The percentage of corporate shares held by first five strategic institutions (Individual/Insiders, Corporations (public), Corporations (private), Company Controlled Foundations, VC/PE firms)

The percentage of corporate shares held by first five state institutions (Sovereign Wealth Funds, State Owned Shares) 
Independent Variables

\section{Corporate Governance}

\begin{tabular}{|c|c|}
\hline Board Size & The number of directors in the board of directors \\
\hline Women on Board (\%) & The percentage of women in the board of directors \\
\hline Independent Director (\%) & The percentage of independent directors in the board of directors \\
\hline & Control Variables \\
\hline Firm Size & The natural logarithm of Total assets \\
\hline$R \& D$ & The natural logarithm of R\&D spending \\
\hline Company Age & The difference between the year of foundation and 2015 \\
\hline Leverage & Total long-term debt divided by total assets \\
\hline growth of Sales & The percentage change of the average sales volume year by year \\
\hline Vol. 3 EBITDA & Three-year standard deviation of EBITDA \\
\hline & CEO characteristics \\
\hline Tenure & The difference between year of appointment and 2015 \\
\hline Founder & Dummy variable, which equals to 1 , if CEO was a founder (co-founder) of a company, 0-otherwise. \\
\hline Gender & Dummy variable, which equals to 1 , if CEO is male, 0 -otherwise. \\
\hline Degree & Accumulated score of educational level: Bachelor $=1$, Master $=2$, Ph. D. $=3$. \\
\hline
\end{tabular}

